\title{
Characteristic of multi-ethnic settlement in Indonesia, a case study: Kampung 3-4 Ulu Laut settlement on Musi Riverbank in Palembang City
}

\author{
Endy Agustian ${ }^{1 *}$, Rini Rachmawati ${ }^{2}$, Raden Rijanta ${ }^{2}$ and Agus Joko Pitoyo ${ }^{3}$ \\ ${ }^{1}$ Faculty of Geography, Universitas Gadjah Mada, Yogyakarta, Indonesia \\ ${ }^{2}$ Department of Development Geography, Faculty of Geography, Universitas Gadjah Mada, Yogyakarta, Indonesia \\ ${ }^{3}$ Department of Environmental Geography, Faculty of Geography, Universitas Gadjah Mada, Yogyakarta, Indonesia
}

\begin{abstract}
The plurality found at Kampung 3-4 Ulu Laut settlement on Musi Riverbank in Palembang city is one example of a case that can represent multi-ethnic settlement in Indonesia. The settlement consists of various kinds of ethnic, including native Palembang ethnic, Palembang Cirebon ethnic, Palembang Chinese ethnic, and migrant ethnics from areas outside of Palembang city. The existence of various multi-ethnic groups has influenced several physical sites of settlement, economic activities, social-cultural activities, and the basic values of life in settlement. This research aims to explore the empirical evidence at Kampung 3-4 Ulu Laut, so the characteristics of the settlement can be identified. The research method used is a case study research method that focuses on individual representation of a group, organization, situation, event or phenomenon in a natural context. Data is collected through a variety of data collection techniques, including documents, archival records, in-depth interviews, direct observation, and physical devices. The results showed that there were cultural variations between ethnic groups, both from the physical side of settlement, economic activities, social-cultural activities, and the basic values of life, which indirectly became a characteristic for settlement of Kampung 3-4 Ulu Laut on Musi Riverbank in Palembang city.
\end{abstract}

\section{Introduction}

The concept of diversity refers to differences between social groups, such as nationality, ethnicity, class, age, gender, ability, education, religion, lifestyle, culture and traditions that must be respected [1-4]. Diversity can be used as a form of local wisdom, local cultural identity, and past production that can distinguish between one region and another [5-7]. Meanwhile, the concept of ethnicity is a group of people who belong to the same lineage, race or nationality and has the same different culture based on religion, geography, language, culture, customs, and shared practices used by each individual where related to loyalty and kinship [8-9].The existence of a collection of ethnic groups is a cultural carrier, which consists of a group of people who have a strong superior culture from an ethnic group, prepared to distinguish ethnic identity between one group and another group [8][10].

Indonesia is an example of a country with a great diversity in the world. It can be seen from the diversity of the people which consists of various nationalities, ethnicities, customs, culture, religion, and language [1112]. The view of diversity life is not something new in Indonesia because the concept of Unity in Diversity can be integrated in a single unit. Based on that concept, the existence of multi-ethnic settlement in Indonesia can be identified by the basis of lineage, religious background or beliefs, the basic values of life, habits, customs, norms, language, history, geographical conditions, and kinship relations.

Kampung 3-4 Ulu Laut is a multi-ethnic settlement located on Musi Riverbank in Palembang city. The settlement consists of including native Palembang ethnic, Palembang Cirebon ethnic, Palembang Chinese ethnic, and migrant ethnics from areas outside of Palembang city. The settlement can be categorized as a settlement with slum potential if not managed properly, because there are several problems related to the environmental conditions of settlement on riverbank, namely due to densely populated areas, limited land supply, and limited public space [13]. The communities that use riverbanks as settlement are the most vulnerable of socially and physically, in addition they are included in homogeneous, their settlement patterns are grouped and reinforced with cultural values and traditions [1415]. The case study of this research can represent multiethnic settlement in Indonesia whose communities are diverse and represent cities that grow on the banks of coastal and river [16].

Kampung 3-4 Ulu Laut is a multi-ethnic settlement in Palembang city as an old city due to social migration factors from rural areas and outside of Palembang city. The existence of Kampung 3-4 Ulu Laut can be seen in how multi-ethnic communities in the settlement living and carrying out their life arrangements. The mixing

* Corresponding author: endyagustian@gmail.com 
between ethnic groups in the settlement did not make some conflicts related to ethnic issues, because there had been assimilation between ethnic groups that could be reflected in marriage ceremonies and language use in daily life [17]. Thus, the phenomenon at Kampung 3-4 Ulu Laut shows the variations from the physical side of settlement, economic activities, social-cultural activities, and the basic values of life which indirectly become own characteristics of Kampung 3-4 Ulu Laut as a multi-ethnic settlement on Musi Riverbank in Palembang city.

\section{Methods}

Humans are social creatures who need a place to live as individuals, groups or organizations to protect, get health, develop, socialize, be educated, and reproduce [18]. A place in particular refers to residential buildings and generally referred to as settlement [19-21]. This research aims to explore the empirical evidence at Kampung 3-4 Ulu Laut as multi-ethnic settlements on Musi Riverbank in Palembang City, so the characteristics of the settlement can be identified. The characteristics of a settlement can make a sense of identity and social ownership in the community which have an important role in realizing a sustainable settlement based on physical and non-physical criteria, including: spatial, behavioural, cultural, and socioeconomic settings [22-23].

The method used in this research is case study research method. The case study research method is a method that aims to collect facts that are naturalistic and can reveal problems based on natural phenomena (empirical evidence), so it cannot be manipulated. The case study research method is considered appropriate because it emphasizes the question of how and why [24]. The case study research method has several sources of evidence that can be used as a focus for data collection to explore research aims, including: documents, archival records, interviews, direct observation, and physical devices [24]. Data collection conducted in this study refers to the indicators of this research, namely by collecting data relate to phenomena contained in the domain of spatial planning, including: physical aspect (space and artifact), activities (economic and socialcultural), and the phenomenon of the basic values of life.

\section{Results}

\subsection{Physical Aspect}

Physical aspect of Kampung 3-4 Ulu Laut can be seen from the land use of settlement that are dominated by settlement land. The large number of migrants gave direction to the composition of settlement that filled the space at the front and back of the settlement.

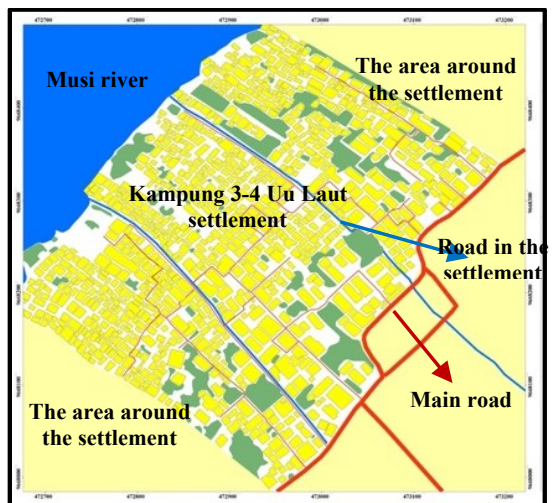

Fig. 1. Land use map of Kampung 3-4 Ulu Laut

Based on the settlement land use, it can be seen that the settlement pattern of Kampung 3-4 Ulu Laut is divided into two parts, namely at the front of the settlement forming a colonization pattern, while at the back of the settlement forming a spread pattern. At the front of Kampung 3-4 Ulu Laut, the settlement pattern is based on kinship because it is intended for Palembang descendants which are from the same family lineage, such as native Palembang ethnic, Palembang Cirebon ethnic, Palembang Chinese ethnic. On that basis, it causes them to colony or group regularly according to their ethnicity at the front of Kampung 3-4 Ulu Laut. Meanwhile, at the back of Kampung 3-4 Ulu Laut, the settlements are more intended for migrant ethnics who come from areas outside of Palembang city. The population growth at the back of Kampung 3-4 Ulu Laut is very fast and dense, it because the settlement to spread irregularly. The pattern of spreading settlement is indirectly formed because of the potential from the socio-economic side that can support the lives of local people. The existence of the Musi River has indirect potential for the local community because it provides work space for them as a getek (boat) driver. On the other side, the swarming of communities in the back of the Kampung 3-4 Ulu Laut also has the potential for fellow migrants to open a trade by selling various kinds of food that are intended for the local community).

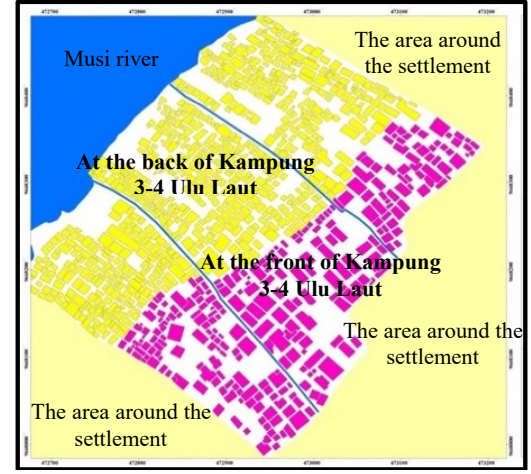

Fig. 2. Settlement pattern map of Kampung 3-4 Ulu Laut

Based on the ethnic groupings, there are differences in the orientation of the house applied by each ethnic. Based on its orientation, people belonging to Palembang descendants (including native Palembang ethnic, Palembang Cirebon ethnic, Palembang Chinese ethnic) build a house in the form of Limas house that overlooking the Musi River by forming settlement patterns that cluster or colonize. This has something to 
do with the philosophy of Limas house that face the position of the sun rise in the east and set in the west. Based on the story of the ancestors, the orientation of settlement that face the Musi river aims to facilitate the transportation because of many activities on the Musi River at the time, and also to get a cool atmosphere.

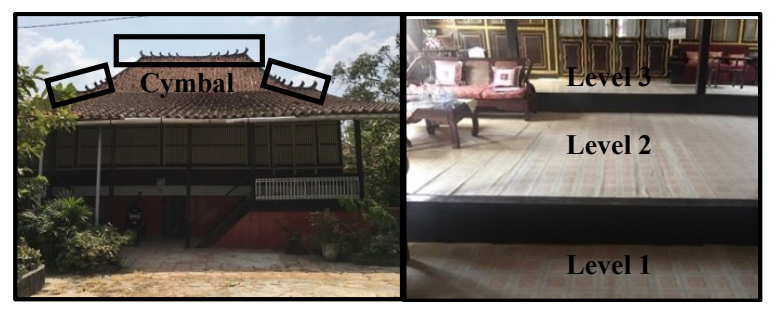

Fig. 3. Limas house at Kampung 3-4 Ulu Laut

One of the characteristics of Limas house is the cymbals decorations on the roof and built facing to the sun, in this case leading to the Musi River. Inside the house there are levels on the floor of the house (kijing), then the roof is equipped with five cymbals. The existence of these cymbals has a function as a lightning rod. The number of cymbals has different meanings, such as 2 cymbals symbolizing Adam and Eve, 3 cymbals symbolize the sun, moon and stars, 4 cymbals symbolizing the companion of the prophets, then 5 cymbals symbolizing the Five Pillars of Islam.

Meanwhile, for migrants ethnic from outside of Palembang city there are no specific rules relating to the orientation of the position or the placement of houses in the settlement. The settlements of migrant ethnics are flexible and adjust the availability of land supply by building warehouse house.

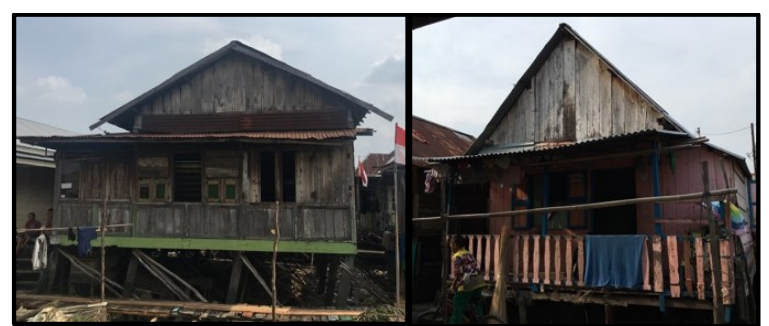

Fig. 4. Warehouse house at Kampung 3-4 Ulu Laut

One of the reasons that house is named to be a warehouse house is because of the shape of the house that resembles a warehouse. The house is identical to an empty room without skating that limits the room, then is equipped using high poles. The warehouse house does not have a philosophy, because the function of the warehouse house is only for a place to live like the general public. Most warehouse houses are chosen by community of Kampung 3-4 Ulu Laut because of their more efficient maintenance and there are no specific provisions regarding the shape and orientation of the house.

\subsection{Economic Activities}

Economic activities at Kampung 3-4 Ulu Laut consist of three groups of livelihoods: trading, laboring (casual daily), and managing nipah. This economic activity can be a source of resilience for the local community for their survival. The principle of collaboration between husband and wife in finding sources of income becomes a concept applied by the local community to meet every day needs that are very simple or mediocre. The principle of collaboration between husband and wife aims to increase the source of income of the local community by working together. The husband's profession works as a casual daily laborer and trades, while the wife sells food at home.

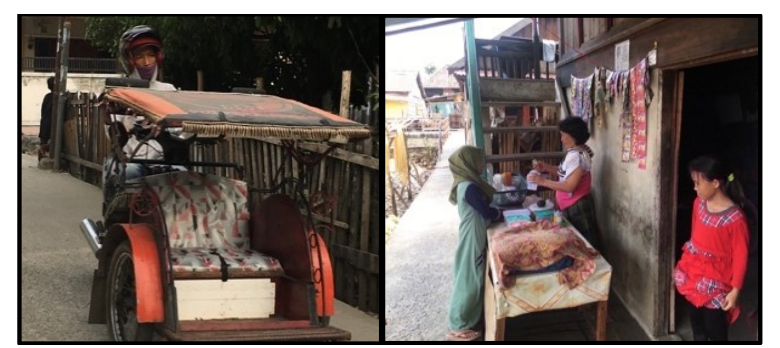

Fig. 5. Economis activities at Kampung 3-4 Ulu Laut (1)

On the other side, the women at Kampung 3-4 Ulu Laut took hired to peel nipah leaves by making art from the palm nipah. Peeling nipah has been an activity that has been carried out by the community at Kampung 3-4 Ulu Laut since the 1970s and has been hereditary from previous ancestors.

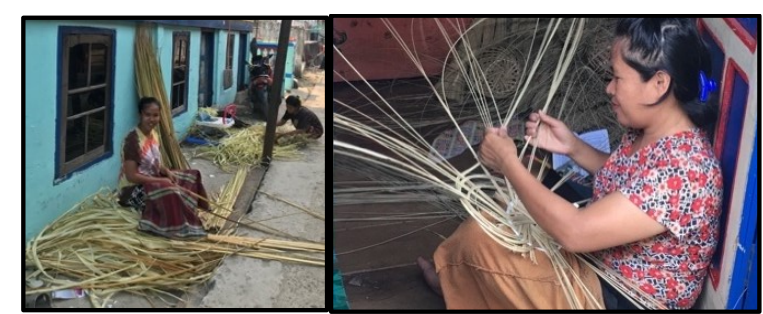

Fig. 6. Managing nipah at Kampung 3-4 Ulu Laut

Initially the local community made these crafts using private capital. However, over time the materials used to make the craft were hard to come, so they decided to take wages from traders who would market the matting in the local market. The activity was carried out by the community at Kampung 3-4 Ulu Laut in addition to increase their income as well as to spend their free time. Under these conditions, the income obtained by the community was only able to meet the basic needs of everyday life.

\subsection{Social-Cultural Activities}

\subsubsection{Baba Boentjit Market}

Baba Boenjit Market is held every Sunday morning or coincides with other important activities. Baba Boenjit market is held in a house that is equipped with a very wide field with a direction that faces directly to the Musi River. The house is owned by a Chinese descendant named Ong Tuan and passed on to his fifth child named Boenjit or Om Boenjit, so the house is named as Baba Boenjit's house. Baba Boenjit market concept like a festival that presents several offerings such as foods to handicrafts in the form of a waste that has been made by the local community. 


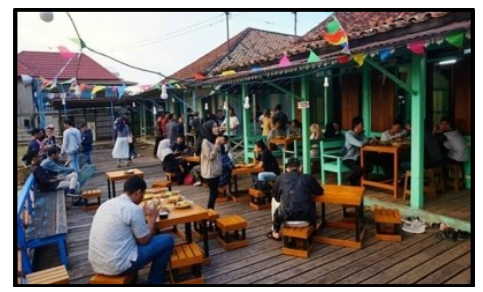

Fig. 7. Managing nipah at Kampung 3-4 Ulu Laut Source: Instagram (@pasarbababoentjit)

The presence of Baba Boentjit market indirectly contributes to the environment around of Kampung 3-4 Ulu Laut. The existence of this market has raised the handicraft (woven) which is a characteristic of the local community, which indirectly can promote and sell a value of nipah managed by the local community. Furthermore, every festival that is held at Baba Boentjit Market always uses a local community getek or boat to be used by every visitor, so it can helps the local community's income. Then, for every important activity such as the August celebration, Baba Boentjit house provides a place (field) to be used by the local community as a place to celebrate the activity.

On the other side, Baba Boentjit market also shows in terms of carvings and the shape of the house that contains elements of a mixing of Chinese and Palembang culture which makes the house has a very high selling and historical value. Baba Boentjit house is almost 300 years old and has never been renovated or replaced. The house has a very high meaning of tolerance because based on its history the house was inhabited by 5 religions living under one roof.

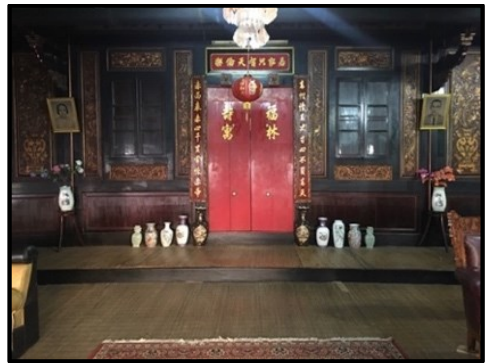

Fig. 8. On the inside of Baba Boentjit house (Mixing of Chinese and Palembang culture)

\subsubsection{Religious Activities}

Religious activities at Kampung 3-4 Ulu Laut are related to Islam, such as praying 5 times in congregation, recitation held once a week, lectures or tausiah held once a week and tahlilan at the time of the death. These religious activities are carried out at Kampung 3-4 Ulu Laut mosque or at the mushollah located in each hall and at the same time become the center of religious activities. The implementation of these activities not only involved by the community at Kampung 3-4 Ulu Laut, but also attended by people from outside of Kampung 3-4 Ulu Laut. Based on this explanation, it can be concluded that the togetherness between all interethnic communities can be closely intertwined as well as the surrounding environment.

The religious phenomenon that is very visible at Kampung 3-4 Ulu Laut during the congregational prayer. The echoes of the call to prayer are heard very clearly in every corner of settlement. Mosques and mushollah that are spread evenly within the settlement are crowded by local and surrounding communities to pray in congregation. In addition, religious studies and lecture activities are also routinely carried out in the village. The religious lectures were specifically attended by local mothers' associations and presenting lecturers from Kampung 3-4 Ulu Laut and also from the outside of Kampung 3-4 Ulu Laut.

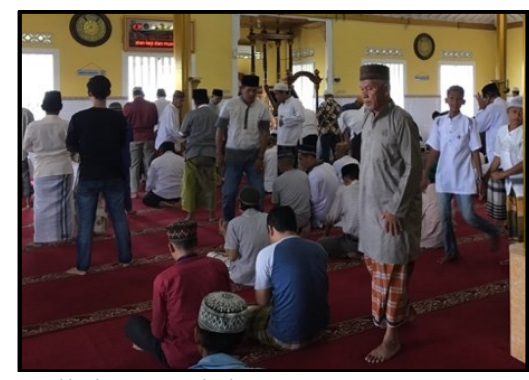

Fig. 9. Religious activity at Kampung 3-4 Ulu Laut

Other religious activities are related to the event of death. Kampung 3-4 Ulu Laut has an union that deals with the death of all local people, which is called the Association of Death Charities. The union has been established since 2009 with 250 members. The purpose of the union is to collect contributions or donations from the local community in the amount of $\mathrm{Rp} 3.000$ per house without coercion. The overall total of the amount of contributions obtained is directly handed over to the people who are currently in disasters through the Association of Death Charities. In the event of a tragedy of death at Kampung 3-4 Ulu Laut, all local people from various ethnic groups and groups will directly come to the house of the community concerned to hold tahlilan.

\subsubsection{The Mutual Coorperation Culture}

The mutual cooperation culture has been attached to a long time ago in the lives of community at Kampung 34 Ulu Laut and it is still practiced today in 2020. The mutual cooperation culture carried out by the local community and it is not only done by an ethnic group, but also all the people in settlement who come from various ethnic groups participate if they get the command to do the mutual cooperation. The mutual cooperation culture often carries out at Kampung 3-4 Ulu Laut in marriage activities, road construction, and cleaning of the environment. Thus, the existence of the mutual cooperation culture in addition to bring together an ethnic communities and also it shows a sense of concern between the community and the surrounding environment.

The mutual cooperation culture in weddings is shown by the local community by helping each other to prepare the things needed for the wedding. Before the wedding, the local community formed a committee and held a study session during one week before the day of the event. Each community has its own division of tasks, such as the program, consumption, and security. The division of tasks between communities is very visible in 
terms of preparing for the consumption of events conducted by local mothers. Meanwhile, the division of tasks related to the arrangement of the place, the stage of the event, or matters relating to the technicality of the event were carried out by local men. For people who are not directly involved in the committee, they still participate in helping the things needed to support the smooth running of the event.

Another the mutual cooperation culture applied at Kampung 3-4 Ulu Laut is in the construction of settlement roads and cleaning up garbage in the neighborhood. In 2008 the local people made a routine mutual assistance program to clean up trash at Kampung 3-4 Ulu Laut. The program is carried out every Sunday morning.

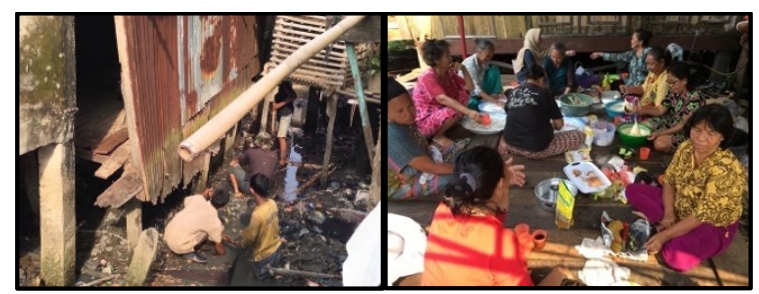

Fig. 10. The mutual cooperation culture by local community at Kampung 3-4 Ulu Laut

\subsection{Basic Values of Life}

The basic values of life adopted by the community at Kampung 3-4 Ulu Laut which is a multi-ethnic society are based on the principle of ethnics. The principle of ethnics is an understanding that is held firmly by all communities in the settlement including native Palembang ethnic, Palembang Cirebon ethnic, Palembang Chinese ethnic, and migrant ethnics from areas outside of Palembang city. The principle is related to the value of faith which is based on the teachings of Islam, such as performing prayers and reading the bible (Al-Qur'an), and the principle of tolerance. The existence of these principles as social capital that is hereditary from the previous ancestors and has been embedded of the community at Kampung 3-4 Ulu Laut.

Since childhood, the local people especially Palembang descendants have always been required by their parents to pray 5 times a day and do not leave it. The teaching of the bible (Al-Qur'an) is also given by their parents which is always held every night after the Magrib Prayer. On that basis, they are always in the house to study and lock the lawang (door) which has become a necessity for security. Until now, the principles that have been given since long ago are still applied by each of these ethnic groups. It can be seen in the appearance of their house on the front of the settlement which always closes and locks the lawang (door) during the Magrib prayer call. This phenomenon indirectly distinguishes between Palembang descendants and migrants ethnic from the back of the settlement who still roam outside the house even though it is late at night.

As a multi-ethnic society, the principle of ethnics is applied by not taking care of everything that is related to the interests of each ethnicity, it is because each of them has their own personal affairs. If there is a conflict at
Kampung 3-4 Ulu Laut, especially between migrants ethnic who come from outside of Palembang city, then Palembang descendants ethnic apply the principle of their ethnics by staying indoors and locking lawang (doors) that have become their cultural or characteristic typical of Palembang people. The tolerance value that is instilled and held in high esteem by the local community is the key to create a life harmony of the community at Kampung 3-4 Ulu Laut which is a multiethnic community to always respect each other, unite with one another, and not spreading mutual grudges and hatred between each other. The basic values of life applied by the local community are the principle that has been embedded of community at Kampung 3-4 Ulu Laut as a multi-ethnic settlement. The principle has provided many lessons for local people to live life as almighty of God creatures who must obey the values of existing faith, while maintaining harmonious relationships with fellow human beings. On that basis, even though the lives of local people in mediocre conditions they can still survive until now.

\section{Conclusions}

Studies relating to ethnic concepts have been conducted in various regions in Indonesia. Some of these studies have revealed that there are a number of good ethnic concepts related to the concept of ethnic settlement space, the concept of ethnic community survival, the concept of ethnic identity, and the concept of harmony of ethnic communities [25-29]. The existence of this research indirectly enriches studies related to ethnic concepts in Indonesia, particularly those relating to the characteristics of multi-ethnic settlements in terms of physical aspects, economic activities, socio-cultural activities, and basic values of life.

Kampung 3-4 Ulu Laut is a multi-ethnic settlement on Musi Riverbank in Palembang City. Physical aspects contained in settlements indirectly represent ethnic distribution. Meanwhile, the non-physical aspects of settlement can be seen based on the empowerment of the local community. Beside, there are various socialcultural activities at Kampung 3-4 Ulu Laut as a space for mutual interaction between communities in the settlement and communities around the settlement. As a multi-ethnic settlement, the basic values of life applied by the local community as a principle that has been embedded in the lives of community at Kampung 3-4 Ulu Laut. The principles held by the local community are related to the value of faith which is based on the teachings of the Islamic religion and the principle of tolerance. On that basis, even though the lives of local people in mediocre conditions they can still survive until now.

\section{References}

1. M. Adam, Bell L, Goodman D.J, Joshi, K.Y, Teaching for Diversity and Social Justice, Routledge: New York and London, 2016. 
2. Kirton G, and Greene A.M, The Dynamics of Managing Diversity. Routledge: London and New York, 2016.

3. Coppin A, Diversity and Inclusion, The Human Capital Imperative, pp. 93-97, 2017.

4. Moreno L and Colino C, Diversity and Unity in Federal Countries, McGill-Queens University Press, Montreal \& Kingston: London, Ithaca, 2010.

5. Bolotio R, Thanksgiving and Ketupat: Local Wisdom Dimensions and Ride of Religious Harmony in North Sulawesi, IOP Conf. Series: Earth and Environmental Science, 175, 2018, http://doi.org/10.1088/1755-1315/175/1/012134.

6. Pesurnay A.J, Local Wisdom in a New Paradigm: Applying System Theory to the Study of Local Culture in Indonesia. IOP Conf. Series: Earth and Environmental, 175, 2018, http://doi.org/10.1088/1755-1315/175/1/012037.

7. Obert $\mathrm{J}$ and Potts S, The Sudan: Unity and Diversity in Multicultural State, Routledge: Sudan, 2016.

8. Keyes C.F, Towards a New Formulation of the Concept of Ethnic Group, Ethnicity, 3, pp. 202130, 1976.

9. Tarling $\mathrm{N}$ and Gomez E.T, The State, Development and Identity in Multi-ethnic Societies: Ethnicity, Equity and The Nation, Routlledge: London and New York, 2008.

10. Barth F, Introduction, in Ethnic Groups and Boundaries, ed. by F. Barth. Boston: Little, Brown, Boston, pp. 9-38, 1969.

11. Na'im A and Syaputra H, Kewarganegaraan, Suku Bangsa, Agama, dan Bahasa Sehari-hari Penduduk Indonesia, Jakarta: Badan Pusat Statistik, 2010.

12. Butler D, Peace and Harmony in the World Based on Pancasila and Bhinneka Tunggal Ika (Unity in Diversity), Jurnal Multikultural \& Multireligious, 15, pp. 33-40, 2016.

13. Rachmawati R, Prakoso E, Sadali M.I, Yusuf M.G, Riparian Planning in Yogyakarta City, IOP Conf. Series: Earth and Environmental Science, 148, hal. 1-12, 2018, http://doi.org/10.1088/1755-1315/148/1/012009.

14. Taylor J, A Tale of Two Cities: Comparing Alternative Approaches to Reducing The Vulnerability of Riverbank Communities In Two Indonesian Cities, International Institute for Environment and Development (IIED), 27 (2), pp. 621-636, 2015, http://doi.org/10.1177/0956247815594532.

15. Darjosanjoto E.T.S, Design Criteria for Open Space at The Riverbank Area in Kampung Wonorejo Timur, International Journal of Education and Research, 3(4), pp. 417-426, 2015.
16. Fitri M, Harun I.B, Triyadi S, A Typology of Residents of Settlement in Urban Riverbank, Indonesia, Journal of Economics and Sustainable Development, 8(24), pp. 181-191, 2017.

17. Setyawati D, Sariyatun, Suryani N, The Strategy in Improving Students' Tolerance Attitude through the Historical Model of Ethnic Settlements Diversity in Palembang, International Journal of Multicultural and Multireligious Understanding, 5(3), pp. 1-10, 2018.

18. UN Habitat, Urbanization and Development: Emerging Futures, United Nations Human Settlements Programme (UN-Habitat), 2016.

19. Tian Y, Liu Y, Kong X, Restructuring rural settlements based onmutualism at a patch scale: A case study of Huangpi District, central China, Applied Geography, 92, pp. 74-84, 2018.

20. Soylu H, Garden House (Dam) Settlement in Malatya, Turkey, Procedia Social and Behavioral Sciences, 19, pp. 347-353, 2011.

21. Logan $\mathrm{J}$ and Murdie R, Home in Canada? The Settlement Experiences of Tibetans in Parkdale, Toronto. Int. Migration \& Integration, 17, pp. 95 113, 2014, http://doi.org/10.1007/s12134-0140382-0.

22. Dewar D, Todes A, Watson V, Regional Development and Settlement Policy, Routledge: London and New York, 2018.

23. Turgut H, Culture, Continuity and Change: Structural Analysis of Housing Pattern, Squatter Settlement GBER, 1, pp. 17-25, 2001.

24. Yin R.K, Case Study Research Design and Methods, fifth Edition, California Sage Publication, Inc, 2014.

25. Heldayani E, Oktavia M, Nuranisa N, Spatial Perspective in Ethnic Areas in Indonesia, IOP Conference Series: Earth and Environmental Science, 145, 2017, http://doi.org/10.1088/17551315/145/1/012104.

26. Ariestadi D, Antariksa, Wulandari L.D, Surjono, Resilience of Historical Urban Multi-ethnic Settlement: Entrepreneurship and Religiosity Concept of Gresik City, IOP Conf. Series: Earth and Environmental Science, 99, 2018, http://doi.org /10.1088/1755-1315/99/1/012026.

27. Aghsari D, Wekke I, Abbas N, Harmony of Coastal Community Regarding Its Ethnic Religion and Cultural Diversity. IOP Conf. Series: Earth and Environmental Science, 156, 2018, http://doi.org/10.1088/17551315/156/1/012034

28. Widiyanarti T, Multicultural Community Communication Style in Medan City of North Sumatra, IOP Conference Series: Earth and Environmental Science, 175, 2018, http://doi.org/10.1088/1755-1315/175/1/012094. 
29. Sismudjito B and Lubis S, Harmonious Interaction Among Ethnical Communities in Regional Development, Indonesian Journal of Geography, 45(2), pp. 149-157, 2013. 